\title{
CYP2E1 wt Allele
}

National Cancer Institute

\section{Source}

National Cancer Institute. CYP2E1 wt Allele. NCI Thesaurus. Code C52362.

Human CYP2E1 wild-type allele is located within 10q24.3-qter and is approximately $12 \mathrm{~kb}$ in length. This allele, which encodes cytochrome P4502E1 protein, is involved in the metabolism of drugs, ethanol and other xenobiotics. It also plays a role in the oxidative activation of nitrosamines. One allelic variant of the CYP2E1 gene contributes to the poor metabolizer phenotype. Polymorphisms within this gene are associated with increased risk of esophageal cancer. 